\title{
Analysis of Professional Education Military Evaluation System Development for Military Academies
}

\author{
Ke Liu ${ }^{1, \mathrm{a}}$ and $\mathrm{Yi} \mathrm{He}^{2, \mathrm{~b}}$ and Lvshan $\mathrm{Xu}^{3, \mathrm{c}}$ \\ ${ }^{1}$ Associate Professor, Political Officer Education and Training Department, PLA Dalian Naval \\ Academy \\ ${ }^{2}$ Lecturer, Political Officer Education and Training Department, PLA Dalian Naval Academy \\ ${ }^{3}$ Director, Political Officer Education and Training Department, PLA Dalian Naval Academy \\ amqson@qq.com, ${ }^{b} 353171244 @ q q . c o m,{ }^{c} 1253017055 @ q q . c o m$
}

Keywords: military academy; occupational education; troops; evaluation mechanism

\begin{abstract}
As the employer of occupational education cadet graduates of military academies, troops have the best say in evaluation of the effect of occupational education in military academies. Improving teaching quality of occupational education in military academies, making cadet graduates responsive to the needs of military development, is the key to teaching reform in military academies, and the evaluation mechanism for military education in military academies is the most important starting point to improve their teaching quality, mutual promoting and developing. This article analyzes the significance, constitution and measures of establishing evaluation mechanism of occupational education in military academies, and explores to promote the effective mechanism for innovation and development of occupational education in military academies.
\end{abstract}

\section{Introduction}

Evaluation of military academies on occupational education means comprehensive judgment of its value and results. As the employer of occupational education cadet graduates of military academies, troops have the best say in evaluation of the effect of occupational education. This requires military academies should gradually build up their evaluation mechanism, occupational as an important measure for military academies to enhance the efficiency of occupational education, and a necessary requirement for military academies to seek scientific development and ensure the quality of talent training.

\section{Significance of establishing military academy occupational education evaluation mechanism}

The military evaluation mechanism accords with military academy occupational education essential attribute and scientific evaluation system inherent requirement, playing an important theoretical and practical role in promoting troops and academies to jointly cultivate talents and exerting academy occupational education effectiveness.

\subsection{Developing the military evaluation mechanism for joint talent cultivation by troops and academies}

It is an excellent tradition for troops and military academies to work together for cultivation and education. For a long time, troops and academies have been conducting exchanges and cooperation in organizing cadets to conduct practical teaching in troops, selecting outstanding officers to teach in academies, and conducting research cooperation between troops and academies. However, participation of troops in evaluation on academy education is still in a preliminary exploration phase from theory to practice. With innovation and development of occupational education of military academies, it is increasingly necessary to develop the scientific, rational and comprehensive evaluation system. The military evaluation mechanism serves as an important and useful complement to occupational education evaluation. This mechanism will surely promote the 
two-way exchange and interaction between academies and troops, further expanding the joint cultivation functions of troops and academies, promoting all-round enhancement of occupational education quality of military academies.

\subsection{The military evaluation mechanism is an effective way to exert the best efficacy of occupational education in military academies}

The effectiveness of military academy occupational education depends on multiple factors, and the scientific and effective evaluation system is one of the most important dynamic factors. As the employer of cadet graduates, the troops are most familiar with real, objective and comprehensive performance, making scientific and accurate evaluation of the effectiveness of occupational education, of great important and far-reaching significance to examining and reflecting military academy occupational education academy running concept, thoughts, course setting, and teaching methods, solving the bottleneck restricting development of military occupation education, clarifying the orientation and direction of the development of military academies, reforming and innovating current education system of military academies, giving full play to military academy cultivation of high-quality military talents and achieving the maximum efficiency.

\subsection{Military evaluation mechanism means the inherent requirements of military academy occupational education special attributes}

Occupational education is based on the regular higher education, focusing on specific job knowledge requirements. ${ }^{[1]}$ The specific job means the post of a cadet assigned by the troops, requiring vocational education to cultivate the ability of the cadet to get engaged in a certain profession. The special attribute of pre-post training requires the academies to take the needs of troops for talents as the core objective, adhering to the principle of academy running of "focusing on the troop, occupational the troop and approaching the troop and centering on distinctions" ${ }^{[2]}$. And the evaluation of the effectiveness will inevitably achieve effectiveness and pertinence.

\subsection{Establishment of the military evaluation mechanism is the necessity of adapting to the diversification of education evaluation of military academies}

Different from the single evaluation for education with record of formal schooling by higher educational institution, military academy occupational education valuation shows a diversified development trend. In addition to higher educational administrative departments, military academy administrators, teachers, cadets, and experts hired from local sources and troop employer are included. ${ }^{[3]}$ This requires the troops to intensify the evaluation in military academy occupational education and make troops comprehensively participate in evaluation through various channels.

\section{Basic structure of the evaluation mechanism of military academy occupational education}

The evaluation mechanism of military academies is a closely integrated organic whole. In terms of reality and operability, the evaluation mechanism should mainly include the following:

\subsection{Regular research mechanism}

The military research is mainly conducted by military academies. Focusing on different research topics, they conduct regular visits to troops of cadet graduates, listening to reports, conducting questionnaire surveys, holding symposiums and individual exchanges, comprehensively understanding compliance of cadet graduates knowledge, abilities, and innovative qualities with military information construction, focusing on investigating shortcomings of cadet graduates, reflecting their weaknesses and shortages, conducting summaries and analyzing the causes for the problems, developing targeted improvement measures, and taking military research as an important indicator of education evaluation of military academies. 


\subsection{Troop monitoring and feedback mechanism}

Under the guidance of the higher authorities, a full-time or part-time organ shall be established by the Political Departments and Headquarters of the troops, conducting dynamic monitoring on the performance of cadet graduates of military academies and vertical and horizontal comparative analysis, sorting out common characteristics of cadet graduates of various academies, finding common reasons in terms of their sources, and conducting timely feedback, taking the monitoring results as an important reference index for occupational education evaluation, making the system scientific.

\subsection{Information exchange mechanism}

The institutionalized and normalized mechanism of information exchange has very important practical significance for correct understanding, evaluation and improvement of military academy occupational education. This requires, under the unified leadership of higher competent departments, troops and military academies should regularly organize seminars and exchanges, directly participating in military academy occupational education evaluation, jointly participating in the occupational education project research, exerting the Internet, telephones and letters and other means to fully communicate the overall performance of the cadets, gradually achieving real-time information exchanges. On this basis, it is necessary to develop relevant systems and rules, making exchanges between troops and academies institutionalized and normalized.

\subsection{Communication and coordination mechanism}

The communication and coordination mechanism focusing on military occupational education evaluation has not been established, and the academy on the evaluation of occupational education troops has not been constructed affecting the effectiveness of military academy evaluation to certain extent. This communication and coordination mechanism requires that under the leadership of the competent department, a leading group for military occupational education evaluation of military academies consisting of the higher organ, troop and academy leaders should be established and relevant periodic communication and coordination systems should be established. Some problems in establishing and operating military evaluation mechanism can be promptly communicated and coordinated. Exerting close cooperation between troops and academies, achieving comprehensive linkage, sharing and exchanging information.

\section{Measures for establishing military academy occupational education evaluation mechanism}

The occupational education evaluation mechanism of military academies is a complicated systematic project, requiring coordinated and concerted efforts in organizational structures, laws and regulations, information and environment.

\subsection{Multi-lateral cooperation and systematization of military academy occupational education evaluation mechanism}

Multiple participations constitutes organizational guarantee for establishing the timely, smooth and efficient military evaluation mechanism. First, it is necessary for higher authorities to play a leading role. The higher authorities refer to the leading organs of military academies and troops. It is necessary for the higher authorities to establish special offices for coordinating the relations between the academies and the troops, planning and providing macro guidance. Second, it is necessary to give full play to all the military academies. As the direct organizers of occupational education, military academies should actively contact with the troops, comprehensively understanding their comments, taking them as the important basis for improvements. Third, it is necessary to exert the active role of troops. As the source of objective, true and comprehensive information of military academies, troops should cooperate with each other in a positive and responsible attitude, jointly cultivating excellent military professionals, effectively providing 
valuable information and suggestions to occupational education evaluation.

\subsection{Improving the system and ensuring standardization of military academy occupational education evaluation mechanism}

Regulations and systems serve as important prerequisites and system guarantee for ensuring normal and effective operations of military occupational education evaluation mechanism. It is necessary to gradually establish and improve related rules and regulations. It is necessary to summarize typical practices of establishing the evaluation mechanism and conduct thorough research and demonstration under the unified leadership of higher authorities and with reference to effective experience of military academies and troops. It is necessary to consequently establish the joint conference system consisting of the 3 parties of higher authorities, military academies and troops, notification system, orientation contact system, and regular research system and other relevant rules and regulations, and new evaluation indicators, achieving military occupational education evaluation mechanism compliance with relevant rules and regulations and consequent standardization.

\subsection{Building the platform and achieving regular information for military academy occupational education evaluation mechanism}

It is necessary to apply the 2 major network systems of military training and political work, gradually establishing the integrated network information platform for troops and military academies. Military academies may set up special occupational education evaluation websites conducting special online columns, online questionnaire survey and online grading, focusing on cadet cultivation programs, curricula settings, and cadet quality training, having officers (including cadet graduates) conduct online judgments and discussions. Troops may conduct some online columns, promptly access the Internet, getting familiar with the performance of cadet graduates and requirements of the troops for talents. Relying on the officer management system of the troops, it is proper to establish the database of military talents and conduct digital management at all levels, providing timely feedback to all academies. This exchange of information through the Internet platform will eliminate barriers to information sharing due to factors such as time and distance, making available instant communication and resource sharing between military academies and troops.

\subsection{Ensuring normalization of military academy occupational education evaluation mechanism}

To ensure normalization of this mechanism, first of all, the Party Committees shall attach importance. Party Committees of higher authorities, military academies and troops at all levels shall have common understanding, recognizing the importance of the military evaluation mechanism for military talent training, taking measures to support the establishment of this mechanism, enhancing the effectiveness of teaching and education and promoting talent cultivation. Second, it is necessary to create a sound atmosphere, issuing relevant documents, conducting seminars and exchanges, promoting examples and practices, enhancing online publicity, gradually forming common concern and participation. Third, it is necessary to make guarantees in place, making available necessary investments to research, authentication analysis, evaluation and network development. All relevant institutions should positively raise funds to make necessary funds available, ensuring normal operations of the evaluation mechanism and earnestly enhancing the effect of military academy occupational education.

\section{Acknowledgments}

This project, namely No.14GJ003-156 project, was funded by National Social Science Fund Military, Science Project Research on the Training System of Innovative Trinity New Military Talents 2014. 


\section{References}

[1] Zhang Baoshu, Thoughts on Promoting Transformation of Military Academy Education [J]. China Military Science, 2004, (5): 63.

[2] Zeng Ming, et al, Type Structure Characteristics of Foreign Military Academy Education System and Related Enlightenment [J] .University Education Science. 2004, (4): 80.

[3] Zou Weibang, Occupational Education Evaluation [J]. Journal of Xi'an Politics Institute, 2008, (2): 106. 